\title{
IN SEARCH OF EVIL: AFFECTIVE DIMENSIONS OF PRESIDENTIAL ELECTIONS 2018 IN GEORGIA
}

\author{
Marine Chitashvili, Davit Machavariani, \& Otar Sokhadze \\ Department of Psychology, Ivane Javakhishvili Tbilisi State University (Georgia)
}

\begin{abstract}
The paper discusses how employing theoretical elements and interpretive frames of psychoanalytic anthropology, particularly from Lacanian perspective, help to conceptualize and analyze the affective dimensions in elections by creation the image of enemy as evil. Psychoanalytical theoretical vocabulary became the main source to capture affective dimension of politics by analyzing the texts, images and discourse how various emotions are signified in political speech. Election as a conventional public activity involves different political parties declaring their political values and competing to convince the large groups of population to vote for and follow specific discourses in order to get the majority in elections and win by setting parameters through which desire is produced, regulated and channeled (Kolvraa, 2018). The common knowledge of building the electoral discourses involves construction of image of enemy, evil, that has to carry the guilt for the perpetual postponement of utopia (Zizek, 1990), i.e. fulfillment of the emotional pull of certain political ideas. By Lacan human subject is never integrated into the symbolic world of language and traced by feelings of something loss and driven by the desire to recapture the lost enjoyment. By Glynos (2010), Starvakakis (2007) and Zizek (2005) this framework was used to understand the affective dimensions of ideological discourses. "This means that ideological discourses must produce fantasmatic narratives or scenarios which promise a utopian future of full satisfaction" (Kolvraa, 2018). In narratives like fascism, radical nationalism, Stalinism loss of enjoyment is replaced as a "stolen" by the enemy than contributes to maintain expectation of impossible - "a return to the fullness of jouisance in a utopian society" (Kolvraa, 2018). However the question of enjoyment still remains open in terms of affective dimension of political discourse - how it is achieved by the discourses of regaining of lost or defeating the enemy. We are analyzing the concrete presidential elections in Georgia, former soviet and new democratic country as a multidimensional social phenomenon coming from Stalinist and nationalist authoritarian past straggling to establish democratic institutions, laws and regulations, implementing elections as a main source of democratic governance. The case of last presidential elections is discussed as ambiguous model where discourses of enemy is floating form lost to stolen enjoyment of utopian society
\end{abstract}

Keywords: Psychosocial, affective dimension, elections, enemy.

\section{Understanding psychosocial}

Psychoanalytical epistemology, as a new academic and therapeutic discourse, expands from psychology to other fields of social sciences from the very beginning of its existence. Freud used psychoanalysis as a methodology to explore the cultural and social phenomenon from the perspective of unconscious, drives, internalization, defense mechanisms, superego, id, etc. Erich Fromm in his book "Sigmund Freud's Mission: An Analysis of His Personality and Influence" (Fromm, 1978) argues, that Freud's personal interest was more in understanding of mankind, culture, world order and not particularly the patients' behavior. According to Fromm he (Freud) used the clinical material to write the macro theory of interplay of social and individual across the civilization.

Debating the core psychoanalytical concepts and its' applications led to establishing the new paradigms, concepts and hypothesis in anthropology, sociology, political science, law, gender studies, literary critic, cinema, etc. (Bocock, 1977).

Stephen Frosh states that the psychoanalysis contributed to the development of poststructuralist and critical social theories and it itself is a social theory (Frosh, 2012). Frosh as a founder of a new discipline of psychosocial studies looks at psychological, social and cultural applications of psychoanalytic theory. The mostly used concepts are repression (oppressive societies denying their 
subjects to access their desires), projection (explaining the mechanism of racism and war), identification (identity issues), internalization (concept of "ungrieved' due to the collective trauma), and castration (Lacanian idea of "lack", as a core principle of subjecthood, that could not be never achieved). Frosh himself uses the idea of haunting to explore how identities, beliefs, intimacies and hatreds are transmitted across generation and between people. Transmissions of cognitive schemas are widely explored in social psychology on IDPs and traumatized groups. (Hentschel et.al, 1996).

Robert Paul (Paul, 1989) rewiring the different aspects of psychoanalytical anthropology, points that those who use psychoanalysis in anthropology assume that human life is influenced by unconscious and is mirrored in culture and symbols people use and follow in every day life and in social actions. For Paul (1987) collective phenomena are the products of individual minds, thus psychoanalysis could be legitimately applied to interpret social phenomena. Aggression as a central impulse of the individual and society could be understood either in positive outcome of internalization (Freud, 1930) or as a projected outwards and directed toward enemies (scapegoating and splitting also enables group to deal with aggression). Paul (1987) defines applied psychoanalysis as a method to interpret cultural, collective, public bodies of symbolism. This approach has been widely used in recent years to understand the political behavior (Marcus, 2003, Brader, Marcus, 2013, Redlawsk, Lau, 2013, Kølvraa, 2018).

Christoffer Kølvraa (2018) points that Lacanian perspective help to conceptualize and analyze the affective dimensions of politics by analyzing texts, images and discourses - how various emotions are signified in political speech. As stated by Lacan, "discourse is "a necessary structure", that "subsists in certain fundamental relations". These "fundamental relations" are of several different orders: intrasubjective or psychological, intersubjective or social, and relations with the nonhuman world. Discourse, according to Lacan, plays formative and transformative roles in each of these orders." (Bracher, 1994, pp.117).

Election as a conventional public activity involves different political parties declaring their political views and competing to convince the large groups of population to vote for them by using specific discourses through which desire is produced, regulated and channeled. "This means that ideological discourses must produce fantasmatic narratives or scenarios which promise a utopian future of full satisfaction" (Kølvraa, 2018).

In this paper we analyze affective dimensions of transformative narrative of evil/enemy during 2018 presidential elections in Georgia.

\section{Background story and case}

Georgia is one of the newly independent states with the Soviet past gaining independence after dissolution of the Soviet Union in 1991. The country has a long history and is known as one of the oldest civilizations of the world (Reyfied, 2012). In the beginning of XX century (1918-21) Georgia became an independent republic, but soon after was occupied by Russia and became one of the republics of the Soviet Union. In 1990, after declaring independence and becoming the member of UN in 1992, Georgia starts a new era as a new democratic state oriented towards the EU integration (Jones, 2012). Since 2008, after the war with Russia, Georgia's 20\% has been occupied by Russia. In 2014 Georgia signed the association agreement with EU; in addition, it has been declared aspiration to join NATO.

Political development in last 25 years till 2016 encounter civil war, frozen conflicts and then occupation, forced change of governments and turmoil of unrest and civil protest, dramatical changes in social structure and growing social inequality. Georgia by the constitution (the last changes were introduced in 2018) is a parliamentary republic, with very limited power of the President as a representative of the country in foreign relations and supreme-commander-in-chief of defense forces (Constitution of Georgia, 2018).

The presidential elections 2018 (the fifth in raw) was the last direct elections. By the new constitution the next president will be elected by the electoral college, without debates and open ballot. Unexpectedly current elections became the special case for political parties to promote their candidates (even there is no any power assigned to the president other than representative). Intention to gain the office became the vital target.

2018 elections became the hot topic in reports of local and international observers highlighting the usage of hate speech, harsh rhetoric and discriminative statements in media (Benidze et.al, 2018, OSCE ODIHR, 2019).

Presidential elections were held in two rounds. During the first round 25 individuals were participating (CEC, 2018). Only three subjects were running very active pre-electoral campaign - Salome Zourabishvili, independent candidate (backed by the parliamentary constitutional majority party Georgian Dream, GD), Grigol Vashadze (supported by the parliamentary faction, political party - United National Movement, UNM) and David Bakradze (supported by the parliamentary opposition faction, 
political party - European Georgia, EG). These three became the main target of negative campaigning and harsh rhetoric from private and social media, most intensively toward S. Zourabishvili (ISFED, 2018).

The main argument provided by the candidates in their speeches was blaming the opponent as a Russian spy or associated with Russia either in past or present. Media and particularly social media ("Facebook" pages) were accusing two candidates S. Zourabishvili and G. Vashadze of pursuing Russian interests. A large portion of the pages that were active in the "Facebook" space, except for discrediting the election subjects, aimed to discredit the current political processes, civil activists and opinion leaders. Photo and video material published by social media pages show that uniform multimedia technologies are used, indicating that their source of creation may be one organized group (ISFED, 2018).

Two candidates, S.Zourabishvili and G.Vashadze, continued the run-off in second round. The use of negative, harsh and at times violent rhetoric significantly overshadowed the campaign. (OSCE ODIHR, 2019, p. 4-5). The ODIHR EOM noted a widespread use of aggressive and violent rhetoric on TV programs and social media, and during demonstrations as well as in individual statements by many high-ranking party members and public officials. Several statements, including on comparing the election to a civil war and calling for the destruction of their opponents, bordered on xenophobia and hate speech. The ODIHR EOM observed that UNM representatives periodically referred to Ms. Zourabishvili as a "traitor" and called the GD "an immoral armed gang"; during anti-UNM public demonstrations, the UNM was compared to "Nazis, terrorists or Satan" and the organizers called to "destroy or annihilate the party"; GD representatives periodically referred to UNM as a "bloody criminal regime" and their coveted victory as "civil war and revenge"(OSCE ODIHR, 2019, p. 28).

\section{Case Analysis}

The objective of case analysis is to identify affective mechanisms of the electoral campaign in whole. Freud understand social structures as formations to satisfy the individual's need for protection from the threat/enemy. Paul points that psychoanalytically oriented research "attempts to discover the fate of aggression, even-or especially-in societies in which its overt expression is normally inhibited .... Aggressive impulses suppressed within a group or community may be projected outward and directed toward "enemies"'” (Paul, 1989, p. 190-91).

During the presidential election social media (in particular Facebook) became one of the most influential channels to communicate with public. Overall only official 19 FB pages for candidates and supporting parties display 7. 224 posts covered 1,261,968 users who liked these pages. We are analyzing the secondary data of social media covering the both rounds of the elections 2018 concentrating only on messages with discredited character, where Russia is symbolized as an enemy and candidate is accused to serve the Russian interests. The evidence-based reports of International Society for Fair Elections and Democracy (ISFED, 2018) gives the full account on different types of misuse of facts during elections. We use only small part of that data, discrediting messages that vary on large scale. Quantitative data (Table 1) shows the breadth and intensity of that. Discrediting messages were grouped by the themes. Second round repeated statements from the first one and were enriched with new content. Data show that in second round discrediting messages against Grigol Vashadze were intensively used associating him with all the wrongdoings of the UNM government he was a part and mocking him as an alter-ego of UNM and former president Michael Saakashvili.

To show the dynamics of affective dimension we classified discrediting messages contents (DMC) in three groups. First one is the facts (DMC F), the second, half facts with deliberate targeted interpretation (DMC FI), third statements without any facts, pure interpretation (DMC I). In the first round DMC was targeted creating candidate as a symbolic image of real threat, Russia, and allowing opponents freely projecting aggression outwards. In the second round Georgian Dream who took the campaigning on behalf of SZ openly declared that this is "principal choice" against the GV, as UNM representative. The DMC content in second round against GV combined his symbolization as a Russia plus as a threat of past government and its violence, brutality, elective justice, insulting moral authority and values.

The common knowledge of building the electoral discourses involves construction of image of enemy, evil, that has to carry the guilt for the perpetual postponement of utopia (Zizek, 1990), i.e. fulfillment of the emotional pull of certain political ideas. Was there any political idea for the presidential elections? From the very beginning the ruling party Georgian Dream underlined the presidential elections to be less important, thus did not nominate its own candidate and supported independent one. However, unexpected activity from the opposition parties made ruling party to be engaged in full scale. The first round of the election campaign crystalized around the idea to have president not affiliated to any treats Georgia had and has nowadays, i.e. Russia as a major threat of independence of the country. Russia as 
symbol of loss of enjoyment being free country converted to symbolic representation by the candidates as unacceptable (DMC I round). The first-round results (SZ 39\% and GV 38\%) clearly show that none of them worked as acceptable and convincing symbols as enemies).

By Lacan human subject is never integrated into the symbolic world of language and traced by feelings of something loss and driven by the desire to recapture the lost enjoyment. By Glynos (2010), Starvakakis (2007) and Zizek (2005) this framework was used to understand the affective dimensions of ideological discourses.

Table 1. Data from social media targeted on discreditation of presidential candidates.

\begin{tabular}{|c|c|c|c|c|}
\hline candidate & \multicolumn{2}{|c|}{ Salome Zourabishvili (SZ) } & \multicolumn{2}{|l|}{ Grigol Vashadze (GV) } \\
\hline round & $I-01.06-18.10$ & $I I-29.10-02.12$ & $I-01.06-18.10$ & $I I-29.10-02.12$ \\
\hline \#FB pages & 26 & 43 & 27 & 72 \\
\hline \# Posts & 10538 & 8383 & 4766 & 3164 \\
\hline \# likes & 452572 & 721646 & 403417 & 712924 \\
\hline $\begin{array}{l}\text { Discrediting } \\
\text { Massages } \\
\text { Content (DMS) }\end{array}$ & $\begin{array}{l}\text { a) Putin ordered } \\
\text { Ivanishvili to } \\
\text { support SZ } \\
\text { b) No to Salome } \\
\text { betrayer } \\
\text { c) Don't vote for } \\
\text { betrayer }\end{array}$ & $\begin{array}{l}\text { d) SZ against Zviad } \\
\text { Gamsaxurdia ( } 1^{\text {st }} \\
\text { president of } \\
\text { Georgia, symbol of } \\
\text { anti-Russian } \\
\text { nationalist) } \\
\text { e) Voting for SZ is } \\
\text { betraying the } \\
\text { homeland } \\
\text { (archbishop's } \\
\text { statement) } \\
\text { f) No to SZ- } \\
\text { Betrayer of } 2008 \\
\text { war } \\
\text { g) SZ - Resident, } \\
\text { Spy }\end{array}$ & $\begin{array}{l}\text { a) } 2008 \text { video on } \\
\text { positive attitude } \\
\text { toward Russia } \\
\text { b) UNM signed EU } \\
\text { Council resolutions } \\
\text { acknowledging the } \\
\text { war started after } \\
\text { bombing Tskhinvali } \\
\text { c)GV got education } \\
\text { in Russia and is } \\
\text { KGB associate } \\
\text { d) GV was Russian } \\
\text { citizen till } 2009 \text { and } \\
\text { at the same time } \\
\text { Georgian Minister } \\
\text { for foreign affairs } \\
\text { e) GV interview } \\
\text { saying the he is the } \\
\text { part of Russian } \\
\text { culture, i.e. } \\
\text { Russians'candidate }\end{array}$ & $\begin{array}{l}\text { f) visual material } \\
\text { mocking GV } \\
\text { transforming into } \\
\text { Micheil Saakashvili } \\
\left(3^{\text {rd }} \text { president of }\right. \\
\text { Georgia, UNM } \\
\text { founder and leader, } \\
\text { symbol of injustice } \\
\text { and brutality of } \\
\text { 2007-12) } \\
\text { g) No to Misha (as a } \\
\text { symbol of violence) } \\
\text { h) visual material of } \\
\text { riot police during } \\
\text { the } 2007 \text { and } 2011 \\
\text { unrest against } \\
\text { government } \\
\text { i) GV misinterpret- } \\
\text { ting the Patriarch } \\
\text { message (the only } \\
\text { moral authority in } \\
\text { Georgia } \\
\text { j) GV presidential } \\
\text { PR lead by Russian, } \\
\text { i.e. Russian } \\
\text { involvement }\end{array}$ \\
\hline \#DMC Fact & & & 2 & 1 \\
\hline \#DMC half Fact & & & 3 & 3 \\
\hline \#DMC Interpreted & 3 & 4 & & 2 \\
\hline
\end{tabular}

Russian threat and perception of Russia as an enemy is not unequivocal for the political landscape of Georgia ("Alliance of patriots of Georgia" anti-western right-conservative party represented in parliament with faction), thus creating the need for clearer and more adequate enemy. In second-round DMC for GV are clear evidence of such type of mythology creation. In 2012, the first-time in Georgia, government was changed by the elections, UNM (GV) lost elections and GD (SZ supporter) got parliamentary majority seats. From 2016 elections GD has constitutional majority in parliament.

Political rivals run-off second round of presidential elections and GD openly supporting SZ started to appeal to nearest past and directly channeling threatening message of possibility power return of UNM (GV second round DMC). Russia as a threat was replaced by coming back of UNM (DMC for Vashadze), while his ties with Russia still remained to be part of the discourse.

The major shift of composing the image of enemy for the second round was re-exposing the traumatic experience of nearest past where GV as a representative UNM government was exposed as a threat. Actually, two traumas - the long standing and realistic, Russia, was challenged with the new and realistic, UNM. The object of enjoyment (freedom) in case of Russia is lost and in case of UNM, the same is twofold (Russia - lost, and personal security - stolen). The heroes of this myths transformed accordingly. SZ who is born as an emigrant from Georgia after the first occupation of Russia at beginning of XX century is returning to regain lost enjoyment and GV who is born in soviet times, enjoyed all privileges under soviets and UNM, both as a brutal regime, could not be trusted as a reliable personality. This statement (equilibrium of two traumas and dynamics of enjoyment) needs to be supported by the evidence. 


\section{References}

Benidze, M, Bartaia T, Rizhamadze N, Nizharadze E, Kinkladze T, Baramidze R. (2018). Final report of monitoring the 2018 presidential elections. Tbilisi: ISFED. Retrieved March 21, 2019 from https://www.scribd.com/document/402537696/ISFED-Final-Report-of-Monitoring-of-the-2018Presidential-Elections\#from_embed

Bocock R.J. (1977). Freud and the centrality of Instincts in Psychoanalytic Sociology. The British Journal of Sociology, Vol.28, No 4, pp.467-480.

Brader, T, Marcus G.E. (2013). Emotion and political psychology. In L Huddy, D.O. Sears, J.S Levy (Eds.), Oxford handbook of political psychology. (pp. 165-204). Oxford: Oxford University Press.

Bracher, M. (1994). On the psychological and social functions of language: Lacan's theory of the four discourses. In M. Bracher, M.W. Alcorn Jn., R.J. Corthell, F. Massadier-Kenny (Eds.), Lacanian theory of discourse: subject, structure and society. (pp. 107-128). New York and London: New York University Press.

CEC, (2018). October 28, 2018 Election of president of Georgia. Interim report. Tbilisi: Election administration of Georgia. Retrieved January 20, 2019, from http://cesko.ge/eng/elections/2018

Constitution of Georgia. Retrieved February $7, \quad$ 2019, from https://matsne.gov.ge/en/document/view/30346?publication=35

Glynos, J. (2001). The grip of ideology: A Lacanian approach to the theory of ideology. Journal of political ideologies, Vol.6, No.2, pp.191-214.

Gugushvili, A., Kabachnik P. (2015). Stalin is dead, long live Stalin? Testing socialization, structural, ideological, nationalist, and gender hypotheses. Post-Soviet Affairs, Vol.35, issue.1, pp. 1-36.

ISFED, (2018). Interim report of the pre-election monitoring of the runoff- 2018 presidential elections. Tbilisi. Retrieved February 7, 2019, from http://www.isfed.ge/eng/angarishebi/Interim-Report-ofthe-Pre-Election-Monitoring-of-the-Runoff-2018-Presidential-Elections

ISFED, (2018). Second Interim report of the pre-election monitoring of the runoff - 2018 presidential elections. Tbilisi. Retrieved February 7, 2019, from http://www.isfed.ge/eng/angarishebi/Numberof-Discrediting-Facebook-Pages-Tripled-for-the-Runoff-Second-Interim-Report-of-Social-MediaMonitoring

Hentschel U., Sumbadze N., Sadzaglishvili S, Mamulashvili M., Ulumberashvili S. (1996). Defensive and affective-emotional reactions to war: the Abkhazian war as reflected in people's subjective reactions. Psychological reports, Vol.78, issue 1, pp. 134-143.

Jones, S. (2012). Georgia: the political history since independence. London New York: I.B. Tauris.

Kølvraa, C. (2018). Psychoanalyzing Europe? Political Enjoyment and European Identity. Political Psychology, Vol. 39, No.6, pp. 1405-1418.

Marcus G.E. (2003). The psychology of emotion and politics. In D.O. Sears, L. Huddy. R. Jervis (Eds.), Oxford handbook of political psychology. (pp. 182-221). Oxford: Oxford University Press.

Freud, S. (1930). Civilization and its discontents. The standard edition of the complete psychological works of Sigmund Freud. Volume XX1. pp. 59-145. London: Hogarth

Fromm, E. (1978). Sigmund Freud's mission: an analysis of his personality and influence. Gloucester: Peter Smith.

Frosh, S. (2013). Hauntings: psychoanalysis and ghostly transmissions. London: Palgrave.

Frosh, S. (2012). A brief introduction to psychoanalytic theory. London: Palgrave.

OSCE ODIHR. (2019). Georgia presidential elections 28 October 28 November 2019. ODIHR Election observation final report. Warsaw: Office for Democratic Institution of Human Rights. Retrieved February 7, 2019, from https://www.osce.org/odihr/elections/georgia/412724?download=true

Paul, R. (1987). The question of applied psychoanalysis and the interpretations of cultural symbolism. Ethos Vol. 15, N. 1, pp. 82-103.

Paul, R. (1989). Psychoanalytic anthropology. Annual Review of Anthropology, Vol.18, pp.177-202.

Redlawsk, D.P., Lau R.R. (2013). Behavioral decision-making. In L Huddy, D.O. Sears, J.S Levy (Eds.), Oxford handbook of political psychology. (pp. 130-164). Oxford: Oxford University Press.

Reyfield, D. (2012). Edge of empires: a history of Georgia. London: Reaktion Books.

Stavrakakis, Y. (2007). The Lacanian left: Psychoanalysis, theory, politics. Edinburgh, Scotland: Edinburgh University Press.

Zizek, S. (2005). Interrogatin the real. London, United Kingdom: Continuum 